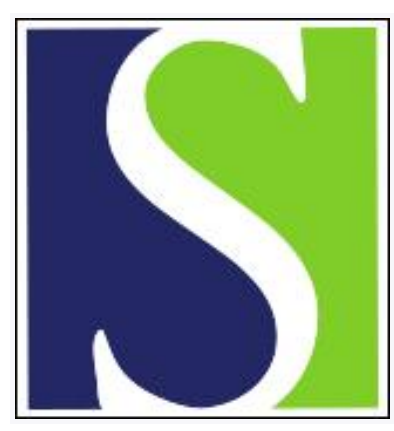

Scand J Work Environ Health 1996;22(5):346-352

https://doi.org/10.5271/sjweh.152

Issue date: Oct 1996

\title{
Occupation and the risk of lung cancer in Uruguay
}

by De Stefani E, Kogevinas M, Boffetta P, Ronco A, Mendilaharsu M

Key terms: amorphous silica dust; asbestos; construction; lung cancer; pesticide

This article in PubMed: www.ncbi.nlm.nih.gov/pubmed/8923607

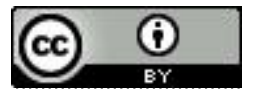




\title{
Occupation and the risk of lung cancer in Uruguay
}

\author{
by Eduardo De Stefani, MD, ${ }^{1}$ Manolis Kogevinas, PhD, ${ }^{2}$ Paolo Boffetta, MD, Alvaro Ronco, MD,' \\ Maria Mendilaharsu, Bsc ${ }^{1}$
}

\begin{abstract}
De Stefani E, Kogevinas M, Boffetta P, Ronco A, Mendilaharsu M. Occupation and the risk of lung cancer in Uruguay. Scand $J$ Work Environ Health 1996;22:346-52.

Objectives The purpose of this study was to provide more information regarding the risk of lung cancer associated with asbestos, pesticides, and other exposures in the Uruguayan work force.

Methods This multisite case-referent study was part of a large project designed for evaluating the role of occupational exposures in cancer risk in Uruguay. According to the design employed, cases were a subset of the data base corresponding to a particular site (in this instance lung cancer), and they were compared with all other sites combined (referents).

Results Significant increases in risk associated with workers in the construction industry were mainly observed for squamous-cell carcinoma. Asbestos, silica dust, and DDT (dichlorodiphenyltrichloroethane) exposure were also associated with increases in the risk of lung cancer. Pipefitters, bakers, and textile workers were also at increased risk of developing lung cancer.

Conclusions Workers employed in the construction industry, as well as those exposed to DDT may have an excess risk of lung cancer. These findings are particularly important in showing that developing countries like Uruguay display risk patterns of similar magnitude as those observed in developed communities.
\end{abstract}

Key terms asbestos, construction, lung cancer, pesticides, silica dust.

Lung cancer is the most frequent malignant disease among the male population of Uruguay with an incidence rate of 74.0 per 100000 (1). Mortality from lung cancer in Uruguay is among the highest of the American countries, following closely the United States and Canada, and it is increasing with time (2-3). Previous studies in Uruguay have shown the dominant role of tobacco smoking in the etiology of the disease, with an attributable risk of $85 \%$ (4). In a previous case-referent study (5) it was estimated that about $22 \%$ of all lung cancer could be attributed to occupational exposures, and a higher risk of lung cancer was observed among construction workers, welders, and electricians. This finding suggests that exposure to asbestos may be widespread among the Uruguayan work force. In addition, agricultural workers displayed a twofold excess in risk for small-cell carcinoma of the lung. Since agricultural workers represent about $20 \%$ of the employed population in Uruguay, this country constitutes a convenient place for studying the possible association between lung cancer risk and pesticide exposure. We conducted a case-referent study designed specifically to describe the possible role of exposure to asbestos, pesticides, and other occupational exposures in the risk of lung cancer in Uruguay.

\section{Subjects and methods}

This study was part of a large multisite case-referent study aiming to estimate the importance of different occupational exposures for the occurrence of cancer in Uruguay. All incident cases occurring in men between 30 and 75 years of age and admitted to the five major hospitals in Montevideo, Uruguay, in the period January 1993 to December 1994 were interviewed shortly after admittance by a team of trained social workers. All sites and histologies were considered eligible for the study. The response rate was high $(97.4 \%)$, and the patients were extremely cooperative. The reasons of nonresponse were refusals $(2.0 \%)$ and poor physical condition $(1.6 \%)$. According to data from the National Cancer Register,

1 Registro Nacional de Cancer, Instituto Nacional de Oncologia, Montevideo, Uruguay.

2 Institut Municipal d'Investigacio Medica, Barcelona, Spain.

3 Unit of Environmental Cancer Epidemiology, International Agency for Research on Cancer, Lyon, France.

Reprint requests to: Dr Eduardo De Stefani, Registro Nacional de Cancer, Avenida Brasil 3080, dep 402, Montevideo, Uruguay. 
interviewed cases represented $40.0 \%$ of all the incident cases registered in the same period in Montevideo $(43 \%$ of the cases and $36 \%$ of the referents).

The distribution of cases by cell type is shown in table 1. Squamous-cell carcinoma was the most frequent $(50.7 \%)$, followed by adenocarcinoma $(21.1 \%)$, and small-cell lung cancer $(12.2 \%)$. In table 2 , the referents are classified by cancer site (International Classification of Diseases, ninth revision). Colorectal cancer was the most common site $(30.6 \%)$, followed by prostate $(23.7 \%)$ and malignant lymphoma ( $8.1 \%)$.

The questionnaire covered sections on sociodemographic variables, tobacco smoking, alcohol drinking, a complete occupational history, specific questions concerning the use of several substances, an asbestos section including relevant job titles and probing questions for each job title, and a section on pesticide use for agricultural workers and garden owners. The part of the questionnaire evaluating exposure to asbestos was an abridged version of a series of supplementary questionnaires used in a German study on risk factors for lung cancer (6).

For each occupation held for at least one year, age of employment, year of hire, and duration of the exposure was recorded. The subjects employed in each occupation were compared with subjects never employed in the corresponding occupations.

Furthermore, estimates of exposure to specific substances were carried out for each patient, according to the principles previously employed by Jockel et al (6). According to the strategy proposed, each cancer site is examined as a case series, using the remaining cancer sites as referents.

In the present study lung cancer patients constituted the case series. The remaining sites, with the exception of cancer of the oral cavity, pharynx, esophagus, stomach, larynx, and bladder, constituted the reference series. The reason for excluding these sites in the reference group was the anatomic proximity or the likelihood of shared occupational etiologies. A total of 270 cases and 383 referents were included in the study. The age distribution was slightly wider for the referents. A larger proportion of lung cancer patients lived in the capital city of Montevideo, and a smaller percentage lived in the northern region of the country. The cases were somehow less educated and with lower incomes than the referents, but the differences were nonsignificant.

Relative risks, approximated by the odds ratios (OR), were estimated for each job title and substance, after control for major confounders, through stratified analysis and unconditional logistic regression (7). The decisions as to which covariates would be included in the final models were based on the biological plausibility, the level of significance when entered into the model (at 0.10 ) and confounding (whether the covariate acted as a confounder of the primary association of interest).
(Confounding was considered present if the regression coefficient of the primary independent variable changed more than $10 \%$ after the addition of the potentially confounding variable to the model.) Among the potential confounders, age, residence, education, income, tobacco smoking (in pack-years), and alcohol consumption fulfilled the criteria and were included in all the models. More complex models included interaction terms between job titles or substances with tobacco smoking and sociodemographic variables. All the calculations were performed using EGRET and GLIM programs (8-9).

\section{Results}

The odds ratios for selected job titles, after adjustment for major confounders, is shown in table 3 . The only job titles associated with significantly elevated odds ratios were bricklayers (OR 1.6) and finishers (OR 1.6). Increased risks were also observed for butchers (OR 2.0), shoemakers (OR 4.8), pipefitters (OR 1.9), textile workers (OR 2.3), and plumbers (OR 2.2). There was a significant effect for textile workers with duration of employment; longer duration of textile work being associated with a fourfold increase in risk. When job titles were classified by cell type, important differences resulted (table 4). Significantly elevated odds ratios for construction workers (bricklayers, finishers) were associated with

Table 1. Distribution of cases by cell type.

\begin{tabular}{lcc}
\hline Cell type & Number & $\%$ \\
\hline Squamous cell & 137 & 50.7 \\
Small cell & 33 & 12.2 \\
Adenocarcinoma & 57 & 21.1 \\
Large cell & 9 & 3.3 \\
Carcinoma (not otherwise stated) & 34 & 12.6 \\
\hline Total & 270 & 100.0 \\
\hline
\end{tabular}

Table 2. Distribution of referents by cancer site.

\begin{tabular}{lcr}
\hline Site $^{a}$ & Number & $\%$ \\
\hline Colon and rectum (153-154) & 117 & 30.6 \\
Prostate (185) & 91 & 23.7 \\
Malignant lymphoma (200-202) & 31 & 8.1 \\
Skin (172-173) & 23 & 6.0 \\
Kidney (189) & 23 & 6.0 \\
Sarcomas (171) & 21 & 5.5 \\
Leukemia (204-208) & 19 & 4.9 \\
Other sites & 15 & 3.9 \\
Nervous system (191-192) & 11 & 2.9 \\
Penis (187) & 10 & 2.6 \\
Testis (186) & 9 & 2.4 \\
Multiple myeloma (203) & 8 & 2.1 \\
Gall bladder (156) & 5 & 1.3 \\
\hline Total (140-208) & 383 & 100.0 \\
\hline
\end{tabular}

a Code of the International Classification of Diseases, $9^{\text {th }}$ revision, in parentheses.

- Cancer of the salivary gland, liver, nose and male breast. 
Table 3. Relative risks of lung cancer for job titles with at least five cases exposed to asbestos. $(\mathrm{OR}=$ odds ratio, $95 \% \mathrm{Cl}=95 \%$ confidence interval)

\begin{tabular}{|c|c|c|c|c|c|c|c|c|}
\hline \multirow[t]{3}{*}{ Job title } & \multirow{3}{*}{$\begin{array}{c}\text { Cases } \\
\text { (N) }\end{array}$} & \multirow{3}{*}{$\begin{array}{l}\text { Referents } \\
\text { (N) }\end{array}$} & \multicolumn{6}{|c|}{ Length of exposure } \\
\hline & & & \multicolumn{2}{|c|}{$1-20$ years } & \multicolumn{2}{|c|}{$\geq 21$ years } & \multicolumn{2}{|c|}{ Ever exposed } \\
\hline & & & $O R^{a}$ & $95 \% \mathrm{Cl}$ & $O R^{a}$ & $95 \% \mathrm{Cl}$ & $\mathrm{OR}^{\mathrm{a}}$ & $95 \% \mathrm{Cl}$ \\
\hline Mechanic & 12 & 28 & 0.3 & $0.1-1.0$ & 0.9 & $0.4-2.6$ & 0.6 & $0.3-1.2$ \\
\hline Electrician & 11 & 14 & 0.9 & $0.2-3.2$ & 1.1 & $0.3-3.4$ & 0.9 & $0.4-2.3$ \\
\hline Welder & 18 & 22 & 0.5 & $0.1-2.0$ & 2.1 & $0.9-4.7$ & 1.4 & $0.7-2.8$ \\
\hline Metal worker & 9 & 15 & 1.2 & $0.3-4.8$ & 1.3 & $0.4-3.8$ & 1.3 & $0.5-3.1$ \\
\hline Roofer & 44 & 48 & 0.9 & $0.4-2.1$ & 1.4 & $0.8-2.6$ & 1.3 & $0.8-2.0$ \\
\hline Bricklayer & 95 & 83 & 1.6 & $0.9-2.7$ & 1.7 & $1.0-2.8$ & 1.6 & $1.1-2.4$ \\
\hline Finisher & 96 & 92 & 1.6 & $0.9-2.7$ & 1.5 & $0.9-2.5$ & 1.6 & $1.1-2.3$ \\
\hline Plasterer & 5 & 9 & 1.1 & $0.2-5.4$ & 0.4 & $0.1-2.5$ & 0.7 & $0.2-2.3$ \\
\hline Truck driver & 30 & 47 & 1.1 & $0.5-2.2$ & 0.9 & $0.5-1.9$ & 0.9 & $0.6-1.7$ \\
\hline Tractor driver & 28 & 35 & 1.7 & $0.8-3.6$ & 0.7 & $0.3-1.6$ & 1.1 & $0.6-2.0$ \\
\hline Miner & 9 & 11 & 0.9 & $0.2-3.3$ & 0.8 & $0.2-3.2$ & 0.8 & $0.3-2.2$ \\
\hline Plumber & 5 & 4 & 2.4 & $0.2-32.9$ & 2.1 & $0.4-10.7$ & 2.2 & $0.5-8.9$ \\
\hline Baker & 11 & 9 & 2.6 & $0.7-9.6$ & 1.1 & $0.3-4.3$ & 1.7 & $0.7-4.4$ \\
\hline Painter & 18 & 22 & 0.9 & $0.2-3.0$ & 1.4 & $0.6-3.1$ & 1.2 & $0.6-2.4$ \\
\hline Glass worker & 16 & 23 & 0.6 & $0.3-1.6$ & 1.7 & $0.6--4.9$ & 0.9 & $0.5-1.9$ \\
\hline Pipefitter & 21 & 16 & 1.3 & $0.4-3.7$ & 2.8 & $1.1-7.4$ & 1.9 & $0.9-4.0$ \\
\hline Butcher & 15 & 12 & 2.1 & $0.6-7.0$ & 2.0 & $0.7-6.2$ & 2.0 & $0.9-4.7$ \\
\hline Leather workers & 4 & 6 & 0.7 & $0.1-4.4$ & 1.3 & $0.2-9.9$ & 0.9 & $0.2-3.6$ \\
\hline Textile & 11 & 8 & 1.4 & $0.4-5.1$ & 4.8 & $0.9-24.2$ & 2.3 & $0.9-6.1$ \\
\hline Farmer & 112 & 161 & 1.1 & $0.7-1.8$ & 1.3 & $0.7-2.5$ & 1.2 & $0.8-1.8$ \\
\hline Forestry worker & 12 & 14 & 1.1 & $0.3-3.9$ & 1.5 & $0.5-4.9$ & 1.3 & $0.6-3.2$ \\
\hline Shoemaker & 7 & 2 & . & & & & 4.8 & $0.9-24.9$ \\
\hline Carpenter & 10 & 13 & 1.5 & $0.5-4.8$ & 0.7 & $0.2-2.9$ & 1.1 & $0.5-2.7$ \\
\hline
\end{tabular}

a All the estimates were adjusted for age, residence, education, tobacco smoking (in pack-years), and alcohol consumption.

Table 4. Relative risks of lung cancer, stratified by cell type, for job titles. ( $\mathrm{OR}=$ odds ratio, $95 \% \mathrm{Cl}=95 \%$ confidence interval)

\begin{tabular}{|c|c|c|c|c|c|c|c|c|c|}
\hline \multirow[t]{2}{*}{ Job title } & \multicolumn{3}{|c|}{ Squamous cell } & \multicolumn{3}{|c|}{ Small cell } & \multicolumn{3}{|c|}{ Adenocarcinoma } \\
\hline & $N$ & $\mathrm{OR}^{\mathrm{a}}$ & $95 \% \mathrm{Cl}$ & $N$ & $O R^{a}$ & $95 \% \mathrm{Cl}$ & $N$ & $O R^{a}$ & $95 \% \mathrm{Cl}$ \\
\hline Mechanic & 10 & 0.7 & $0.3-1.7$ & 1 & 0.5 & $0.1-3.7$ & - & . & . \\
\hline Electrician & 11 & $\begin{array}{l}0.1 \\
1.5\end{array}$ & $0.6-3.8$ & - & & $0.1-0.1$ & 1 & 0.5 & $0.1-3.9$ \\
\hline Plumber & 5 & 2.7 & $0.5-13.5$ & - & . & . & - & $\cdot$ & \\
\hline Welder & 17 & 1.2 & $0.5-2.9$ & 1 & 0.8 & $0.1-6.6$ & 2 & 0.9 & $0.2-3.9$ \\
\hline Metal worker & 8 & 0.8 & $0.2-2.9$ & 1 & 1.6 & $0.2-14.2$ & 3 & 2.3 & $0.6-8.8$ \\
\hline Roofer & 39 & 1.1 & $0.6-2.1$ & 5 & 0.9 & $0.3-2.9$ & 6 & 0.8 & $0.3-1.9$ \\
\hline Bricklayer & 89 & 1.7 & $1.1-2.8$ & 9 & 0.8 & $0.3-2.1$ & 21 & 1.7 & $0.9-3.2$ \\
\hline Finisher & 90 & 1.9 & $1.2-3.0$ & 7 & 0.6 & $0.2-1.6$ & 19 & 1.4 & $0.7-2.6$ \\
\hline Plasterer & 5 & 0.9 & $0.2-3.7$ & 1 & 1.0 & $0.1-9.2$ & - & . & \\
\hline Truck driver & 29 & 0.9 & $0.5-1.9$ & 3 & 0.8 & $0.2-3.1$ & 8 & 1.4 & $0.6-3.3$ \\
\hline Tractor driver & 26 & 1.0 & $0.5-2.1$ & 5 & 1.6 & $0.5-5.5$ & 8 & 1.9 & $0.8-4.9$ \\
\hline Miner & 9 & 1.2 & $0.3-4.9$ & 1 & 0.9 & $0.1-9.7$ & - & . & . \\
\hline Baker & 11 & 2.3 & $0.7-6.9$ & 3 & 7.3 & $1.5-35.8$ & 2 & 1.4 & $0.3-7.2$ \\
\hline Painter & 18 & 1.5 & $0.6-3.4$ & 4 & 2.8 & $0.8-9.9$ & 2 & 0.5 & $0.1-2.5$ \\
\hline Glassworker & 15 & 1.1 & $0.4-2.5$ & - & & & 7 & 1.8 & $0.7-4.6$ \\
\hline Pipefitter & 19 & 2.5 & $1.1-5.7$ & 2 & 1.6 & $0.3-9.6$ & 1 & 0.5 & $0.1-3.8$ \\
\hline Shoemaker & 7 & 5.9 & $0.9-36.8$ & 1 & 3.5 & $0.2-49.4$ & 1 & 3.1 & $0.2-41.3$ \\
\hline Butcher & 15 & 2.6 & $0.9-6.9$ & 1 & 1.8 & $0.2-16.9$ & 5 & 2.7 & $0.9-8.3$ \\
\hline Textile & 11 & 0.6 & $0.1-4.8$ & 4 & 10.9 & $2.6-46.5$ & 3 & 4.7 & $1.1-20.3$ \\
\hline Farmer & 104 & 1.3 & $0.8-2.3$ & 14 & 1.9 & $0.7-5.2$ & 18 & 0.7 & $0.3-1.4$ \\
\hline Forestryworker & 12 & 1.8 & $0.6-4.9$ & - & . &.$^{0 . m}$ & 4 & 1.8 & $0.5-6.2$ \\
\hline Carpenter & 10 & 0.8 & $0.2-2.6$ & 2 & 2.2 & $0.4-10.9$ & 3 & $\begin{array}{l}1.0 \\
1.8\end{array}$ & $0.5-6.9$ \\
\hline
\end{tabular}

a All the estimates were adjusted for age, residence, education, tobacco smoking (in pack-years), and alcohol consumption.

squamous cell type, whereas small-cell carcinomas showed significantly increased odds ratios of 10.9 and 7.3 for textile workers and bakers, respectively. Textile work was also associated with a significant increase in risk of adenocarcinoma. Butchers had an increased risk of 2.7 for adenocarcinoma. Farmers had nonsignificant increases in risk for squamous and small-cell lung cancer. In table 5, the odds ratios of lung cancer associated with selected substances are shown. Exposure to Portland cement, brick dust, asbestos, and silica dust was significantly associated with lung cancer (OR values for those ever exposed were 1.6, 1.7, 1.7, and 1.6, respectively). Ever exposure to wood dust was also associated with a $70 \%$ increased risk of lung cancer. Ever exposure to DDT was associated with a $70 \%$ increase in risk (95\% CI 1.0-2.8). In table 6, the OR values for cell 
type are shown for the same substances. Excavation dust, Portland cement, brick and silica dust, and asbestos exposure were associated with significant increased risks only for squamous-cell carcinoma. Exposure to diesel exhaust was associated with a twofold increase in risk for small-cell lung carcinoma, whereas gasoline exposure was associated with a moderate increase in risk for adenocarcinoma of the lung. Ever exposure to DDT resulted in increased risks for small-cell cancer and adenocarcinoma. In table 7, the joint effects of asbestos and tobacco smoking for all cell types, for squamous-cell cancer and for lung adenocarcinoma are shown. For all types and for squamous-cell carcinoma a more than additive effect was found. The joint effects of asbestos exposure and type of tobacco are shown in table 8 . Asbestos exposure was associated with an increased risk for all cell types combined and for squamous cell carcinoma among black tobacco smokers.

\section{Discussion}

The results of our study indicate several associations between job titles and substances and the risk of lung cancer. In fact several hazardous industries are present in developing countries, where the risk is increased by the lack of protective measures (10). This situation is not unknown in Uruguay. In addition, Uruguay is a major cattle and wool producer and occupations like farming are of outstanding importance and allow an assessment of the effects of pesticide exposure in a large sector of the population of Uruguay.

Several findings should be emphasized. Asbestos is a well defined lung carcinogen $(11-14)$, and our results show that $26 \%$ of the study population was exposed to asbestos. Furthermore, the risk appears to be largely confined to squamous-cell cancer. This finding appears to be in accordance with the findings of Baker et al (13), who reported a higher frequency of this cell type among workers exposed to crocidolite.

The subject has been reviewed recently by Vainio \& Boffetta (11). Unfortunately, the type of asbestos fiber to which this population was exposed is rather difficult to assess, given the design employed. Other studies have reported an increased frequency of small-cell lung cancer in relation to mixed and complex exposures to asbestos $(13-14)$.

Silica dust is a probable human lung carcinogen (15). Our results suggest an elevated risk for squamous-cell carcinoma of the lung. Siemiatycki et al (16) were unable to find an association between silica exposure and lung adenocarcinoma, squamous-cell and small-cell lung cancer being the only types associated with this substance.
Table 5. Relative risks of lung cancer for selected substances. (OR $=$ odds ratio, $95 \% \mathrm{Cl}=95 \%$ confidence interval)

\begin{tabular}{|c|c|c|c|c|}
\hline Substance & $\begin{array}{c}\text { Cases } \\
\text { (N) }\end{array}$ & $\begin{array}{l}\text { Referents } \\
\text { (N) }\end{array}$ & $O R^{a}$ & $95 \% \mathrm{Cl}$ \\
\hline \multicolumn{5}{|l|}{ Wood dust (years) } \\
\hline $1-20$ years of exposure & 25 & 20 & 2.1 & $1.1-4.1$ \\
\hline$\geq 21$ years of exposure & 13 & 17 & 1.2 & $0.5-2.5$ \\
\hline Ever exposed & 38 & & & $0.9-2.8$ \\
\hline \multicolumn{5}{|l|}{ Mineral wool dust (years) } \\
\hline $1-20$ years of exposure & 3 & 4 & 1.2 & $0.2-6.3$ \\
\hline$\geq 21$ years of exposure & 4 & 1 & 3.3 & $0.3-31.2$ \\
\hline Ever exposed & 7 & 5 & & $0.5-6.1$ \\
\hline \multicolumn{5}{|l|}{ Fur dust (years) } \\
\hline $1-20$ years of exposure & 10 & 8 & 1.9 & $0.7-5.6$ \\
\hline$\geq 21$ years of exposure & 6 & 8 & 1.1 & $0.4-3.4$ \\
\hline Ever exposed & 16 & 16 & 1.5 & $0.7-3.3$ \\
\hline \multicolumn{5}{|l|}{ Gasoline (years) } \\
\hline $1-20$ years of exposure & 28 & 23 & 1.8 & $0.9-3.2$ \\
\hline$\geq 21$ years of exposure & 24 & 38 & 0.9 & $0.5-1.7$ \\
\hline Ever exposed & 52 & 61 & 1.3 & $0.8-1.9$ \\
\hline \multicolumn{5}{|l|}{ Diesel exhaust (years) } \\
\hline $1-20$ years of exposure & 34 & 40 & 1.2 & $0.7-2.1$ \\
\hline$\geq 21$ years of exposure & 35 & 41 & 1.5 & $0.9-2.5$ \\
\hline Ever exposed & 69 & 81 & 1.3 & $0.9-2.0$ \\
\hline \multicolumn{5}{|l|}{ Gasoline exhausts (years) } \\
\hline $1-20$ years of exposure & 30 & 35 & 1.1 & $0.6-2.0$ \\
\hline$\geq 21$ years of exposure & 30 & 50 & 0.9 & $0.5-1.5$ \\
\hline Ever exposed & 60 & & & $0.7-1.5$ \\
\hline \multicolumn{5}{|l|}{ Excavation dust (years) } \\
\hline $1-20$ years of exposure & 22 & 32 & 1.2 & $0.7-2.3$ \\
\hline$\geq 21$ years of exposure & 49 & 37 & 1.7 & $0.9-2.7$ \\
\hline Ever exposed & 71 & 69 & & $0.9-2.2$ \\
\hline \multicolumn{5}{|l|}{ Portland cement (years) } \\
\hline $1-20$ years of exposure & 44 & 48 & 1.6 & $0.9-2.7$ \\
\hline$\geq 21$ years of exposure & 62 & 56 & 1.6 & $0.9-2.5$ \\
\hline Ever exposed & 106 & 104 & 1.6 & $1.1-2.3$ \\
\hline \multicolumn{5}{|l|}{ Brick dust (years) } \\
\hline $1-20$ years of exposure & 39 & 44 & 1.5 & $0.9-2.5$ \\
\hline$\geq 21$ years of exposure & 62 & 51 & 1.9 & $1.2-2.9$ \\
\hline Ever exposed & 101 & 95 & 1.7 & $1.2-2.5$ \\
\hline \multicolumn{5}{|l|}{ Solvents (years) } \\
\hline $1-20$ years of exposure & 27 & 24 & 1.9 & $1.0-3.6$ \\
\hline$\geq 21$ years of exposure & 44 & 53 & 1.1 & $0.7-1.8$ \\
\hline Ever exposed & 71 & 77 & 1.3 & $0.9-1.9$ \\
\hline \multicolumn{5}{|l|}{ Asbestos (years) } \\
\hline $1-20$ years of exposure & 30 & 38 & 1.5 & $0.8-2.5$ \\
\hline$\geq 21$ years of exposure & 58 & 42 & 1.9 & $1.2-3.1$ \\
\hline Ever exposed & 88 & 80 & 1.7 & $1.2-2.5$ \\
\hline \multicolumn{5}{|l|}{ Silica dust (years) } \\
\hline $1-20$ years of exposure & 42 & 57 & 1.3 & $0.8-2.2$ \\
\hline$\geq 21$ years of exposure & 83 & 75 & 1.8 & $1.2-2.8$ \\
\hline Ever exposed & 125 & 132 & 1.6 & $1.1-2.3$ \\
\hline \multicolumn{5}{|l|}{ Arsenic (years) } \\
\hline $1-20$ years of exposure & 9 & 3 & 3.0 & $0.7-12.4$ \\
\hline$\geq 21$ years of exposure & 3 & 4 & 0.9 & $0.2-4.9$ \\
\hline Ever exposed & 12 & 7 & 1.9 & $0.6-5.3$ \\
\hline \multicolumn{5}{|l|}{$\begin{array}{l}\text { DDT (dichlorodiphenyltri- } \\
\text { chloroethene (years) }\end{array}$} \\
\hline $1-20$ years of exposure & 34 & 33 & 1.6 & $0.9-2.9$ \\
\hline$\geq 21$ years of exposure & 16 & 17 & 2.0 & $0.9-4.7$ \\
\hline Ever exposed & 50 & 50 & 1.7 & $1.0-2.8$ \\
\hline Dieldrin (years) & & & & \\
\hline $1-20$ years of exposure & 17 & 13 & 2.1 & $0.9-4.6$ \\
\hline$\geq 21$ years of exposure & 5 & 18 & 0.4 & $0.1-1.2$ \\
\hline Ever exposed & 22 & 31 & 1.1 & $0.6-2.0$ \\
\hline Other and unknown pesticide & & & & \\
\hline $1-20$ years of exposure & 24 & 44 & 0.8 & $0.5-1.5$ \\
\hline$\geq 21$ years of exposure & 18 & 20 & 2.2 & $1.0-4.6$ \\
\hline Ever exposed & 42 & 64 & 1.2 & $0.7-1.9$ \\
\hline
\end{tabular}

a Adjusted for age, residence, education, cigarette smoking, and alcohol consumption. 
Table 6. Relative risks of lung cancer for workers ever exposed to selected substances by cell type. $(\mathrm{OR}=$ odds ratio, $95 \% \mathrm{Cl}=95 \%$ confidence interval)

\begin{tabular}{|c|c|c|c|c|c|c|}
\hline \multirow[t]{2}{*}{ Substance } & \multicolumn{2}{|c|}{ Squamous cell } & \multicolumn{2}{|c|}{ Small cell } & \multicolumn{2}{|c|}{ Adenocarcinoma } \\
\hline & $\mathrm{OR}^{\mathrm{a}}$ & $95 \% \mathrm{Cl}$ & $0 R^{a}$ & $95 \% \mathrm{Gl}$ & $\mathrm{OR}^{\mathrm{a}}$ & $95 \% \mathrm{Cl}$ \\
\hline Wood dust & 2.1 & $1.1-3.8$ & 2.0 & $0.7-5.9$ & 1.3 & $0.5-3.2$ \\
\hline Wool fiber & 2.2 & $0.5-8.8$ & - & - & - & - \\
\hline Fur dust & 1.1 & $0.4-3.0$ & 1.1 & $0.1-8.9$ & 2.6 & $0.8-8.5$ \\
\hline Gasoline & 0.9 & $0.5-1.7$ & 1.1 & $0.4-3.2$ & 2.0 & $1.0-4.0$ \\
\hline Diesel exhausts & 1.4 & $0.8-2.3$ & 2.0 & $0.9-4.7$ & 1.4 & $0.7-2.8$ \\
\hline Gasoline exhausts & 0.9 & $0.5-1.5$ & 0.8 & $0.3-2.2$ & 1.2 & $0.6-2.3$ \\
\hline Excavation dust & 1.8 & $1.1-2.9$ & 0.9 & $0.3-2.5$ & 1.3 & $0.6-2.6$ \\
\hline Portland cement & 1.9 & $1.2-2.9$ & 1.1 & $0.5-2.6$ & 1.4 & $0.7-2.6$ \\
\hline Solvents & 1.4 & $0.8-2.3$ & 1.6 & $0.6-3.9$ & 1.2 & $0.6-2.4$ \\
\hline Brick dust & 1.9 & $1.2-3.1$ & 1.1 & $0.4--2.6$ & 1.7 & $0.9-3.2$ \\
\hline Silica dust & 1.9 & $1.2-2.9$ & 0.9 & $0.4-2.0$ & 1.5 & $0.8-2.9$ \\
\hline Asbestos & 2.1 & $1.3-3.4$ & 0.7 & $0.3-1.9$ & 1.3 & $0.7-2.6$ \\
\hline Arsenic & 2.3 & $0.7-7.6$ & 2.9 & $0.5-18.1$ & 2.1 & $0.6-8.0$ \\
\hline DDT (dichlorodiphenyltrichloroethene) & 1.3 & $0.7-2.3$ & 3.6 & $1.5-8.9$ & 2.3 & $1.2-4.7$ \\
\hline Dieldrin & 0.9 & $0.4-2.1$ & 2.4 & $0.8-7.7$ & 1.3 & $0.5-3.2$ \\
\hline Other pesticides & 0.9 & $0.5-1.7$ & 0.8 & $0.2-2.9$ & 1.3 & $0.7-2.7$ \\
\hline
\end{tabular}

all the estimates were adjusted for age, residence, education, tobacco smoking (in pack-years), and alcohol consumption.

Table 7. Age- and residence-adjusted relative risks for the joint effect of tobacco smoking and asbestos exposure. (OR $=$ odds ratio, $95 \%$ $\mathrm{Cl}=95 \%$ confidence interval)

\begin{tabular}{|c|c|c|c|c|c|c|c|c|c|c|c|c|}
\hline \multirow[t]{3}{*}{ Tobacco use } & \multicolumn{4}{|c|}{ All cell types of carcinoma } & \multicolumn{4}{|c|}{ Squamous-cell carcinoma } & \multicolumn{4}{|c|}{ Adenocarcinoma } \\
\hline & \multicolumn{2}{|c|}{ Never exposeda } & \multicolumn{2}{|c|}{ Ever exposeda } & \multicolumn{2}{|c|}{ Never exposed ${ }^{a}$} & \multicolumn{2}{|c|}{ Ever exposeda } & \multicolumn{2}{|c|}{ Never exposeda } & \multicolumn{2}{|c|}{ Ever exposeda } \\
\hline & $\mathrm{OR}$ & $95 \% \mathrm{Cl}$ & OR & $95 \% \mathrm{Cl}$ & OR & $95 \% \mathrm{Cl}$ & OR & $95 \% \mathrm{Cl}$ & OR & $95 \% \mathrm{Cl}$ & OR & $95 \% \mathrm{Cl}$ \\
\hline $\begin{array}{l}\text { None (never smokers) } \\
\text { Ever smokers }\end{array}$ & $\begin{array}{l}1.0 \\
8.2\end{array}$ & $4.4-15.3$ & $\begin{array}{r}2.5 \\
14.4\end{array}$ & $\begin{array}{l}0.9-6.6 \\
7.3-28.4\end{array}$ & $\begin{array}{r}1.0 \\
13.2\end{array}$ & $4.7-37.1$ & $\begin{array}{r}3.0 \\
26.9\end{array}$ & $\begin{array}{l}0.6-14.3 \\
9.2-79.1\end{array}$ & $\begin{array}{l}1.0 \\
4.3\end{array}$ & $1.6-11.4$ & $\begin{array}{l}1.6 \\
6.9\end{array}$ & $\begin{array}{l}0.4-8.6 \\
2.4-20.1\end{array}$ \\
\hline
\end{tabular}

a To asbestos.

Table 8. Age- and residence-adjusted relative risks for the joint effect of type of tobacco and asbestos exposure. (OR $=0$ dds ratio, $95 \%$ $\mathrm{Cl}=95 \%$ confidence interval)

\begin{tabular}{|c|c|c|c|c|c|c|c|c|c|c|c|c|}
\hline \multirow[t]{3}{*}{ Type of tobacco } & \multicolumn{4}{|c|}{ All cell types of carcinoma } & \multicolumn{4}{|c|}{ Squamous cell carcinoma } & \multicolumn{4}{|c|}{ Adenocarcinoma } \\
\hline & \multicolumn{2}{|c|}{ Never exposed ${ }^{\mathrm{a}}$} & \multicolumn{2}{|c|}{ Ever exposeda } & \multicolumn{2}{|c|}{ Never exposeda } & \multicolumn{2}{|c|}{ Ever exposeda } & \multicolumn{2}{|c|}{ Never exposeda } & \multicolumn{2}{|c|}{ Ever exposeda } \\
\hline & OR & $95 \% \mathrm{Cl}$ & OR & $95 \% \mathrm{Cl}$ & OR & $95 \% \mathrm{Cl}$ & OR & $95 \% \mathrm{Cl}$ & OR & $95 \% \mathrm{Cl}$ & OR & $95 \% \mathrm{Cl}$ \\
\hline None (never smokers) & 1.0 & & 2.5 & $0.9-6.6$ & 1.0 & & 3.0 & $0.6-14.2$ & 1.0 & & 1.6 & $0.3-8.7$ \\
\hline Blond & 5.1 & $2.6-10.2$ & 9.7 & $4.3-21.7$ & 8.6 & $2.8-26.6$ & 18.4 & $5.5-61.8$ & 4.1 & $1.4-12.4$ & 5.4 & $1.4-20.7$ \\
\hline Black & 9.1 & $4.9-17.1$ & 16.0 & $7.7-33.3$ & 15.2 & $5.3-43.1$ & 32.3 & $10.6-98.4$ & 4.9 & $1.6-12.0$ & 7.9 & $2.5-24.9$ \\
\hline
\end{tabular}

a To asbestos.

Other important associations observed in our study were those with Portland cement and brick dust, and for both substances the higher risks corresponded again to squamous-cell lung carcinoma. Nevertheless, the lack of statistical power assessing associations with small-cell carcinoma and adenocarcinoma should be taken into account. Both exposures are of great interest, given the high proportion of construction workers in our base population (29.7\% of the reference series). These findings congrue with previous results (17).

Pesticides formed one of the main exposures of interest in this study. Our results support an increased risk of lung cancer in general, and of lung adenocarcinoma and small-cell lung cancer in particular, for DDT exposure, and the dose-response pattern was significant, replicating previous findings $(18-23)$. Since the pesticides used in this work force were partly unknown, it is difficult to establish which chemical could be responsible for the increased risk associated with the category of other pesticides. The working group of the International Agency for Research on Cancer concluded that DDT is possibly carcinogenic to humans (group 2B) (23). Nevertheless, the association between lung cancer and DDT exposure should be evaluated cautiously.

We have evaluated the possibility of bias in the results of this study. It is unlikely that selection bias may 
have considerably affected these findings, since all patients admitted to the major hospitals of Montevideo were included in the study.

We also compared the proportion of lung cancers in this base population with the proportion observed in data of the National Cancer Register. The figures were similar and suggest a common catchment area $28.3 \%$ in this study, $22.9 \%$ in the National Cancer Register).

Recall and interviewer biases appear to have been minimized by the design employed in this study. All the patients interviewed were cancer patients, and recall of the exposures under study should have been similar for each cancer site $(24-25)$.

As aptly stated by Siemiatycki et al (15), the main inconvenience of using a cancer reference group is the possibility that the cancers in the reference pool share occupational exposures with the case series and thus dilute a real effect. This possibility was minimized by including all cancer sites with the exception of sites previously considered possibly related with one or more important exposures relevant to the etiology of lung cancer. Finally, our design precluded a better characterization of the exposure, the result being a critical evaluation of the estimates presented in this study.

For a disease like lung cancer, residual confounding from tobacco smoking is always a matter of concern. We tried to minimize this problem by including a term for pack-years in all the analyses. We tried to measure the degree of confounding by tobacco smoking using the confounding risk ratio (CRR), as suggested by Spinelli et al (26). This ratio ranged from 0.70 for mineral wool fiber to 1.30 for concrete dust. In conclusion, this study has provided a rather large number of associations between occupational exposures and lung cancer, and it suggests that smaller previous studies conducted in Uruguay were valid (5).

\section{Acknowledgments}

The work reported in this paper was funded by grants from the International Agency for Research on Cancer, Lyon, France, and the Comision Honoraria de Lucha contra el Cancer, Montevideo, Uruguay.

\section{References}

1. Ronco A, Louise JB, De Stefani E. Cancer incidence in Montevideo, Uruguay. In: Proceedings of the 1993 annual meeting, International Association of Cancer Registries, SlovakiaBratislava, September 13-16, 1993. Slovakia: National Cancer Registry, 1993.

2. Boffeta P, La Vecchia C, Levi F, Lucchini F. Mortality pat- terns and trends for lung cancer and other tobacco-related cancers in the Americas, 1955-1989. Int J Epidemiol 1993; 22:377-84.

3. Parkin DM. Time trends for cancer in developing countries. Chest 1989;96:5S-8S.

4. De Stefani E, Fierro L, Correa P, Carzoglio J, Deneo-Pellegrini $\mathrm{H}$, Zavala $\mathrm{D}$, et al. Type of tobacco and risk of lung cancer: a case-control study from Uruguay. Lung Cancer 1992; $8: 21-8$.

5. De Stefani E, Fierro L, Deneo-Pellegrini H, Carzoglio J, Levin R. Ocupacion y cancer de pulmon en Uruguay: estudio caso-control. Tumor 1990;3:20-5.

6. Jockel KH, Ahrens W, Wichmann HE, Becher H, Bolm-Audorff $\mathrm{U}$, Jahn I, et al. Occupational and environmental hazards associated with lung cancer. Int J Epidemiol 1992;21:20213.

7. Breslow NE, Day NE. Statistical methods in cancer research; Vol I (The analysis of case-control studies). Lyon: International Agency for Research on Cancer (IARC), 1980. IARC scientific publications, no 32.

8. Statistics and Epidemiology Research Corp. EGRET reference manual, revision 3. Seattle (WA): Statistics and Epidemiology Research Corp. 1992.

9. Baker RJ, Nelder JA. The GLIM system, release 3. Oxford: Numerical Algorithm Group, 1978.

10. Pearce N, Matos E, Vainio H, Boffetta P, Kogevinas M. Occupational cancer in developing countries. Lyon: International Agency for Recearch on Cancer (IARC), 1994. IARC scientific publications, no 129.

11. Vainio H, Boffetta P. Mechanisms of the combined effect of asbestos and smoking in the etiology of lung cancer [review]. Scand J Work Environ Health 1994;20:235-42.

12. International Agency for Research on Cancer (IARC). Overall evaluations of carcinogenicity: an updating of IARC monographs volumes 1 to 42 . Lyon: IARC, 1987. IARC monographs on the evaluation of carcinogenic risks to humans, suppl 7.

13. Baker JE, Reutens DC, Graham DF, Sterrett GF, Musk AW, Hobbs MST, et al. Morphology of bronchogenic carcinoma in workers formerly exposed to crocidolite at Wittenoom Gorge in Western Australia. Int J Cancer 1986;37:547-50.

14. Kjuus H, Skjærven R, Langård S, Lien JT, Aamodt T. A casereferent study of lung cancer, occupational exposures and smoking: II, role of asbestos exposure. Scand J Work Environ Health $1986 ; 12: 203-9$.

15. Simonato L, Fletcher AC, Saracci R, Thomas TL. Occupational exposure to silica and cancer risk. Lyon: International Agency for Research on Cancer (IARC), 1990. IARC scientific publication, no 97 .

16. Siemiatycki J, Gerin M, Dewar R, Lakhani R, Begin D, Richardson $L$. Silica and cancer associations from a multicancer occupational exposure case-referent study. In: Simonato L, Fletcher AC, Saracci R, Thomas TL, editors. Occupational exposure to silica and cancer risk. Lyon; International Agency for Research on Cancer, 1990.

17. Siemiatycki J. Risk factors for cancer in the workplace. Boca Raton (FL): CRC Press, 1991.

18. Milham SY. Occupational mortality in Washington State 1950-1979. Cincinnati (OH): National Institute for Occupational Safety and Health (NIOSH), 1983. DHHS, no 83-116.

19. Austin H, Keil JE, Cole P. A prospective follow-up study of cancer mortality in relation to serum DDT. Am J Public Health $1989 ; 79: 43-6$.

20. Wong O, Brocker W, Davis HV, Nagle GS. Mortality of 
workers potentially exposed to organic, inorganic brominated chemicals, DBCP, Tris, PBB and DDT. Br J Ind Med 1984;21: $15-24$.

21. Wicklund, KG, Daling JR, Allard J, Weiss NS. Respiratory cancer among orchardists in Washington state, 1968 to 1980. J Occup Med 1981;30:561 4 .

22. Ditraglia D, Brown DP, Namekata T, Iverson N. Mortality study of workers employed at organochlorine pesticide manufacturing plants. Scand J Work Environ Health 1981;7 suppl $4: 140-6$.

23. International Agency for Research on Cancer (IARC). Occupational exposures in insecticide application, and some pesticides. Lyon: IARC, 1991. IARC monographs on the evalua- tion of carcinogenic risks to humans, vol 53.

24. Linet MS, Brookmeyer R. Use of cancer controls in casecontrol cancer studies. Am J Epidemiol 1987;125:1—11.

25. Wacholder S, Silverman DT, McLaughlin JK, Mandel JS. Selection of controls in case-control studies: II. types of controls. Am J Epidemiol 1992;135:1029-41.

26. Spinelli JJ, Band PR, Gallagher RP. Adjustment for confounding in occupational cancer epidemiology. Recent Results Cancer Res 1990;120:64-77.

Received for publication: 25 October 1995 